\title{
Patient advocacy - Report for Public Policy Committee
}

The Public Policy Committee has recently been examining the issue of patient advocacy and the state of the development of advocacy in the United Kingdom. As yet there is surprisingly little research material of relevance to the UK but a literature search covering the last 20 years revealed a vast quantity of reports on the topic in the USA. Advocacy arose there out of the Civil Rights movement in the 1960 s, when groups of young lawyers took up the cause of 'liberty' and rights for various disadvantaged groups; one of these groups was the mentally ill and mentally handicapped. In the USA at that time the number of people in institutions had reached a peak and federal funds had been cut, with the result that overcrowded treatment conditions, together with undermanned and demoralised staff, proved fertile ground for complaints about the existing system.

Various groups arose advocating the rights of patients:

(a) Legal advocates, who sponsored the 'liberty' movement - the right to freedom and to refuse compulsory treatments.

(b) 'Citizen' advocates, defined as an "unpaid competent citizen who with the support of an independent citizen advocate agency, represents, as if they were his own, the interests of one or two impaired persons by means of one, or several of many, advocacy roles, some of which may last for life" (Wolfsenberger, 1977). Citizen advocates need to be independent of service provision.

In the United States there is statutory provision for advocacy of handicapped people in every state (the Protection \& Advocacy for Mentally Ill Individuals Act, 1986). A review of the workings of this kind of advocacy in California concluded that although it was rather expensive, and used by only $6 \%$ of those eligible, it was useful in obtaining help for patients in housing and social issues. Advocates were found to be insufficiently trained to appreciate the importance of treatment, and the researcher (Binder, 1985) proposed that there should be some way of making advocates legally responsible for adverse consequences of their advice in this respect.

In the UK, the Disabled Persons Act, 1986, deals with the appointment of authorised representatives of disabled people and with the rights of these representations. No actual guidelines as to how the Act is to be implemented have yet been issued.

Already in the UK there are some 'citizens' groups. One is Advocacy Alliance, which has produced Guidelines for One-to-One Advocacy in Mental Handicap Hospitals. Advocacy Alliance is a group of five national voluntary associations which came together to attempt to recruit and train volunteers to look after the needs of long-stay mental handicap patients. A pilot project was set up in St Lawrence, St Ebba's and Normansfield Hospitals. It proved difficult, however, to attract sufficient volunteers of good quality. Not unexpectedly, some volunteers were found to have come to the project as a means of answering their own needs, and others had the aim of reforming the whole system of care; the latter frequently adopted an adversarial approach. There were also problems in training the volunteers, largely because the objectives of training were not sufficiently clear. There was some turnover of paid organisers, which resulted in inconsistencies in training and policy.

The exercise, even for those professional carers who favoured the project, proved time-consuming and traumatic. Nevertheless Professor Bicknell, who was involved in the pilot project, reported that the exercise was worthwhile, and perhaps one must simply conclude that any intervention in established treatment practices is fraught with emotive issues (e.g. Mental Health Act Commission and Health Advisory Service visits). More recently, a National Citizen Advocacy Resource and Advising Centre has been set up to provide information, support and training packages to advocacy organisations.

In other parts of the country, advocacy schemes, using the National Association of Citizen Advice Bureaux as an organisational base, are well established, with the obvious advantage of association with a highly regarded and independent national agency (thus avoiding a segregated service).

Although in some countries, e.g. the Netherlands, advocacy agencies are government funded, there is no statutory funding of such services in the UK. Most are funded by short-term grants from health authorities, social services, voluntary associations, and the DHSS. Insecure funding arrangements are likely to affect staff morale and have obvious consequences for training and recruitment.

It is hoped that the Guidelines to the Disabled Persons Act will clarify the funding issue.

(c) 'Trade Union' advocacy In the USA, many voluntary groups have found that by banding together (in a more political manner than Advocacy Alliance) they have won huge increases in state mental health budgets. For example, in Maryland they managed to increase the budget for the chronic mentally ill by $171 \%$ over five years! (Cromwell, 1988).

(d) Professional advocates Traditionally psychiatrists and mental health workers have seen themselves as their patients' advocates and are often hurt and bewildered when their role is challenged in this respect. In the USA, the American Psychiatric 
Association reacted first defensively, later militantly, to attacks on their right to treat those too ill to decide for themselves, to the extent of hiring their own lawyers to oppose the "liberty issue" lawyers on the other side. However, there is evidence that both sides are seeking common ground, and more lawyers see that it is often in their clients' interests to be treated.

(e) Self advocacy In the late 1960s, large numbers of psychiatric patients in the USA started to speak out against their conditions of treatment. Now there are groups throughout the country, with their own newspaper and own annual conference! They provide mutual support groups, but view psychiatry as oppressive, and refuse to work with psychiatrists. To a lesser degree they also distrust the lawyers!

Already there are a few similar groups in the UK. One, 'Survivors Speak Out', by name alone leaves little doubt that its members do not support present mental health practices.

Less adversarial is the group formed in 1971, known as CMH (Campaign for Valued Futures, with people who have learning difficulties). Its conferences and published reports show that self advocacy groups are now common in the UK but that their style and achievements are variable (The Growing Voice - a survey of self advocacy groups in adult training centres and hospitals in Great Britain). CMH also produces a learning pack (LASA Pack). Another group, People First, crossed the Atlantic to the UK in 1984. It organises self advocacy monthly meetings mainly in the London area. The Kings Fund Centre is a valuable source of information on the whole self advocacy question.

(f) Quality action groups It might be that a way forward for the advocacy movement could be through what have been termed Quality Action Groups. These groups look at components of a service and include people at all levels in that service. For example, people with mental handicap, their families, service staff, managers, politicians and members of the local community might work together, although how to 'empower' the handicapped and their families adequately is an issue which has not been resolved. The Kings Fund Centre has pioneered work on this difficult problem (Pursuing Quality, 1986). It will be important for the work of all such groups to be carefully evaluated and audited.

Approved by the Executive and Finance Committee (September 1989)

\section{References}

Advocacy Alliance (1984) Guidelines for one to one advocacy in mental handicap hospitals.

BiNDER, R. L. (1985) Patients' rights advocates in San Francisco. Bulletin of the American Academy of Psychiatry and the Law, 13, 313-323.

Cromwell, H. S., Howe, J. W. \& O'Rear, G. (1988) A citizens' coalition in mental health advocacy - the Maryland experience. Hospital and Community Psychiatry, 39, 959-962.

The Disabled Persons (Services, Consultation \& Representation) Act, 1986.

National Citizen Advocacy Resource \& Advisory Centre, 2 St Paul's Road, London N1 2QR (Tel: 01-359 8289).

The Protection of Advocacy for Mentally III Individuals Act 1986.

WOLFENSBERGER, W. (1977) A balanced multicomponent advocacy and protection scheme. Toronto: NIMR/ CAMR Publications.

CMH Campaign for Valued Futures with People who have Difficulties. CMH Publications, 5 Kentings, Comberton, Cambridge CB3 7DT.

The Growing Voice - a survey of self advocacy groups in adult training centres and hospitals in Great Britain. $\mathrm{CMH}$ Publications.

People First, 126 Albert Street, London NW1 7NF.

Kings Fund Centre for Health Services Developments, 126 Albert Street, London NW1 7NF.

TYRER, P. (1989) Arming the weak: the growth of patient power in psychiatry. Review of Power in Strange Places (eds I. Barker and E. Peck). Psychiatric Bulletin, 13, 307-308.

\section{Correction}

\section{The responsibility of the child and adolescent psychiatrist in multidisciplinary teams (Psychiatric Bulletin, September 1989, 13, 521).}

The second paragraph of this statement referred to multidisciplinary teams as including 'educational psychiatrists'. This should have read 'educational psychologists'. 